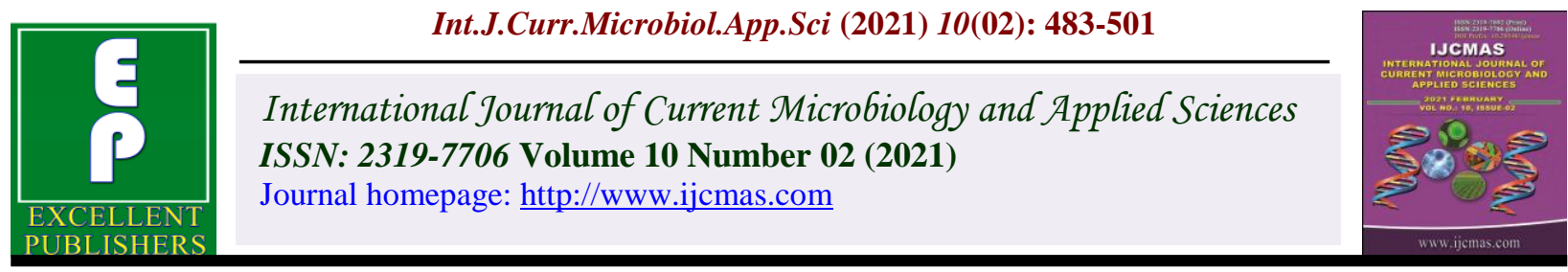

Original Research Article

https://doi.org/10.20546/ijcmas.2021.1002.057

\title{
An Investment Pattern in Banana Plantations of Tamil Nadu
}

\author{
M. Karthikeyan ${ }^{1 *}$, Zhou Deyi ${ }^{1}$ and C. Sekhar ${ }^{2}$ \\ ${ }^{1}$ Division of Agricultural Economics and Management, Huazhong Agricultural University, \\ Wuhan, China \\ ${ }^{2}$ SRS Institute of Agriculture and Technology, Vedasandur, Tamil Nadu, India \\ *Corresponding author
}

A B S T R A C T

\begin{tabular}{|c|}
\hline Keywords \\
\hline $\begin{array}{l}\text { Banana, Investment } \\
\text { pattern, Costs and } \\
\text { return, Farm } \\
\text { efficiency } \\
\text { measures }\end{array}$ \\
\hline Article Info \\
\hline $\begin{array}{l}\text { Accepted: } \\
\text { 07 January } 2021 \\
\text { Available Online: } \\
\text { 10 February } 2021\end{array}$ \\
\hline
\end{tabular}

\section{Keywords}

Banana, Investment pattern, Costs and parn, Farm efficiency

Article Info

Accepted:

Available Online:

10 February 2021
The study was aiming to address the economic incentives that are associated with cultivation of different varieties of Banana in Central Tamil Nadu because the farmers in the Cauvery Belt are practicing the traditional method of Banana cultivation instead of precision approaches. In this circumstance, a study has been initiated to address the reasons behind it as well as assessing the type of costs involved and the returns realized per unit of land. From this study, one could understand that the Nendran and Yelakki varieties of Banana are able to fetch considerable revenue than the other varieties. Efficiency measures indicated that Rasthali variety is also equally contributive but its genetic potential were not utilized by applying appropriate technologies.

\section{Introduction}

Banana is the vast produced and maximum consumed amongst the fruits cultivated in India. The area under Banana is reflecting an increasing trend which was raised to 8.46 lakh ha during 2015 - 16 from 6.58 lakh ha during the year 2007-08 registering a 29 per cent increase in the area. Such increase is invisible in respect of annual crops other than Banana. The area and production of Banana over years had given a marginally increasing signal to the nation (NHB, 2018). India ranks first amongst the Banana cultivating countries of the world with an annual production of 297 lakh tonnes during 2013-14 which decreased to the level of 291 lakh tonnes during the year 2015-16. The reason for sliding from 297 lakh tonnes to 291 lakh tonnes need to be examined and appropriate strategies have to be implemented to enhance the production and productivity of Banana. The present production of Banana in the country however, is highly inadequate. It is appraised that, the present annual per capita consumption of Banana in India is $50 \mathrm{~kg}$ which is very low when compared with other progressive Banana growing countries such as Jamaica, 
Congo, Ecuador and Uganda. Thus, there is a vast opportunity of increasing Banana production in the country to meet the needs of ever increasing population.

When comparing the production data in respect of Banana over a decade of time, it showed a fluctuation trend from 238 lakh tonnes during 2007-08 and 291 lakh tonnes during the year 2015-16. In the middle of the years, the production of Banana even has touched to the level of 298 lakh tonnes. In the meantime, production of Banana faced lots of ups and downs due to variation in productivity which is hovering between 34 tonnes to 37 tonnes per ha. It might be due to erratic weather and rainfall. But the data revealed that the 2016-17 is being the normal year and there was no much damage. Low realization of productivity might be due to the lack of precision approaches in realizing the higher productivity. For that the awareness creation exercise by the Department of Horticulture and Plantation Crops should take an appreciable effort to scale up the precision farming practices in Banana. On doing the planned action of promotion of Precision Farming, the productivity would touch a new height and pave way for the higher export earnings from Banana and its produce.

However, the productivity of Banana showed a mixed trend over years revealed that the precision technologies applicable to Banana is not at all practiced positively. If the precision technology was adopted in a phased manner, the production and productivity of Banana would have touched a new peak due to sustained efforts. Another issue is investment cost. Though the details on cost of production and cost of cultivation of Banana is known to the farmers through their sustained cultivation practices, a comparative picture on different varieties and its cost and return realization are dismal to the farming lots and hence an effort has been taken to appraise the costs and returns realizable in different varieties of
Banana cultivated in Tamil Nadu.

\section{Materials and Methods}

\section{Design of the study}

In Tamil Nadu Banana cultivation is widely practiced because of its commercial importance and consumer acceptance. The farmers of different regions were cultivating Banana based on their experience gained over generations. However, in Central Tamil Nadu, though the resources are much conducive, their way of practicing Banana farming is little traditional and hence special effort has been taken to identify the Banana farmers and their cultivation practices and an economic appraisal was made for different varietal cultivation of Banana.

\section{Selection of the study area}

The area under Banana in Tiruchirappalli District is arrived at 7002 ha. When one could compare the area under Banana in the state of Tamil Nadu, Trichy is in fifth place and Erode District is in the first place with 12335 ha. When one could compare the productivity of Banana, Coimbatore District is in the first place with 42.49 Tonnes per ha followed by 42.31 Tonnes per ha with Erode District. Tiruchirappalli District is in the Third place in productivity revealed that there exists potential to expand the area and yield of Banana in Trichy district. However, Trichy district is augmented with different varieties of Banana because of suitability of soil and climate. The varieties cultivated in Tiruchirappalli District are Sakkai, Poovan, Ney Poovan, Red Banana, Rasthali, Monthan, Karpuravalli, Peyan, Yelakki, Nendran and Grand Naine are cultivated widely in this district and have to assess the reasons for being in the fifth place in respect of area under banana, reasons for the preference of farmers to raise different varieties in their farm lands for cultivation and to explore the 
possibilities of enhancing the productivity of Banana in Tiruchirappalli District. The Productivity of Banana is only 39 tonnes per ha in Tiruchirappalli District. Whereas, Theni and Cuddalore Districts outperformed other districts and other states in terms of Productivity of Banana and in possession of 64 tonnes and 59 tonnes respectively. In this context, assessing the reasons for low productivity too is much important to the researcher.

\section{Sampling procedure}

Tiruchirappalli district was once popular in area and production of Banana in Tamil Nadu and stood at the first place have been eroded in area and production of Banana during recent years and stood in fifth place in terms of area under Banana. Considering the potentials available in the district, the Indian Council of Agricultural Research, New Delhi has also established a National Research Centre for Banana in Tiruchirappalli due to the favorable soil, climate and other factors for conducting Banana Research. On the other side, the banana production and productivity was low in Tamil Nadu state, it might be due to some pressing problems in cultivation of Banana and in this circumstance it is important to the researcher to analyze the reasons for the reduction in area, production and productivity and hence Tiruchirappalli district was purposively chosen in the first stage. Tiruchirappalli district consists of fourteen blocks with 507 revenue villages. Among the 14 blocks available in Tiruchirappalli District, the blocks like Lalgudi, Anthanallur and Thottiyam occupied with 75 per cent of total Banana area available in Tiruchirappalli District and hence these three blocks were purposively chosen in the second stage.

Among the three blocks, five villages from each block were selected at random. Totally
15 villages with 300 farmers were selected as sample size for the study through multi stage random sampling technique. They were interviewed for generating primary data through a structured and pretested questionnaire designed for that purpose.

\section{Period of study}

The period of study was restricted to the agricultural year 2017-2018 (Normal Year) with normal rainfall, which is sufficient for undertaking the purpose and an in-depth study.

The field enquiry was conducted from the month of May to November 2018 to collect the data requirement of the study. The data presented are related to the agricultural year of 2017.

\section{Design of interview schedule}

A reconnaissance survey was undertaken before shaping the research problem and the researcher met the farm households in person, officials of Department of Agriculture, Department of Horticulture and Plantation Crops, Department of Economics and Statistics, Tahsildars and other revenue officials such as Revenue Inspectors and Village Administrative Officers to have a holistic view about the agricultural production scenario especially the Banana cultivation in the study area and to ensure the availability of consistent, relevant, accurate and adequate data for the study. Additional information gathered and personal observations made during the preliminary survey formed the basis for developing hypotheses.

Based on the preliminary survey, the interview schedule was prepared in consultation with the experts in the field of agricultural economics of Tamil Nadu Agricultural University, Coimbatore. The 
interview schedules thus prepared were pretested to evaluate its field applicability with some selected respondents and the questionnaire has been revised and the final edition of the questionnaire was prepared and multiple copies were made to perform the inquiry with the sample respondents.

\section{Method of inquiry}

The selected farm households have been personally contacted and the required primary data were collected through interview method by administering the pre tested interview schedules.

The objectives and importance of the study were explained to the respondents briefly to solicit their co-operation. Supervision has been taken to record the quality data by administering the questions repeatedly if the researcher feels inconsistency in getting the answers.

\section{Tools of analysis}

\section{Conventional analysis}

Simple average and percentage analysis were used to study the farm oriented variables such as size of operational holdings, irrigation sources, cropping pattern, inputs used, cost of cultivation, costs and returns involved in Banana, yield of different varieties of Banana, Price of output, farm income, crop loans disbursed and the resource availability in the farms.

\section{Co-efficient of variation}

Co-efficient of variation of the selected variables such as crop expenses, crop income, yield of crops, value of assets and resource endowments were worked out to study the variations in the above said variables in the farms across scale of farming (Table 1).

\section{Cost concepts}

The technique of tabular presentation was used to assess the cost, returns and profits of crops in the study area. The percentages and averages of variable costs and fixed costs were computed based on the methodology followed by the Commission on Agricultural Costs and Prices (CACP).

All the cost concepts used in farm management studies viz., Cost $A_{1}$, Cost $A_{2}$, Cost $B_{1}$, Cost $B_{2}$, Cost $C_{1}$, Cost $C_{2}$ and Cost $\mathbf{C}_{\mathbf{3}}$ were used in the present study. The details of cost concepts adopted in this study are furnished as follows:

\section{Cost $A_{1}-$ It includes the following Costs}

Value of Human Labour

Value of Machine Labour

Value of Manures and Fertilizers

Cost of Seeds

Plant Protection Chemicals

Irrigation Charges

Land Revenue, Cess and other taxes

Depreciation Charges on farm implements, machinery, buildings, irrigation structures

Interest on Working Capital and Miscellaneous Expenses

Cost $A_{2}:$ Cost $A_{1}$ plus Rent paid for leased in land.

Cost $B_{1}$ : Cost $A_{2}$ plus Interest on fixed capital (excluding land).

Cost $\mathbf{B}_{2}$ : Cost $\mathrm{B}_{1}$ plus Rental value of owned land.

Cost $\mathbf{C}_{1}$ : Cost $\mathrm{B}_{1}$ plus Imputed value of family labour.

Cost $\mathrm{C}_{2}$ : Cost $\mathrm{B}_{2}$ plus Imputed value of family labour. 
Cost $\mathbf{C}_{3}$ : Cost $\mathrm{C}_{2}$ plus $10 \%$ of Cost $\mathrm{C}_{2}$ to account for managerial input of the farmer.

Cost of Production: The cost of cultivation was worked out by using following formula:

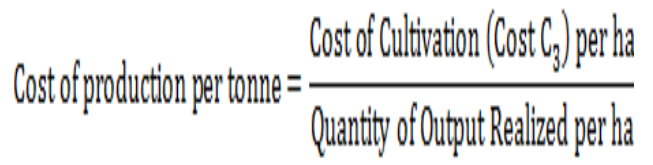

Similar methodology was practiced by Ramakrishna et al., during 2017 and Agarwal et al., during 2018 by using Cost C3 as cost of cultivation. However, in this study, the author has used Cost $\mathrm{C} 2$ to assess the total cost of cultivation.

Income measures: Following income measures were calculated.

Gross Income (GI): It is calculated by using the following formula.

$\mathrm{GI}=(\mathrm{Qm} \times \mathrm{Pm})$

Where,

$\mathrm{GI}=$ Gross Income

Qm = Quantity of Main Product in Kgs

$\mathrm{Pm}=$ Price of Main Product per $\mathrm{Kg}$

Returns over Variable Cost (RVC)

$\mathrm{RVC}=$ Gross Income - Cost $\mathrm{A}_{1}$

Farm Business Income (FBI)

FBI $=$ Gross Income - Cost $\mathrm{A}_{2}$ Similar approach was also practiced by Agarwal et al (2018)

Family Labour Income (FLI) or Returns to Family Labour

$\mathrm{FLI}=$ Gross Income - Cost $\mathrm{B}_{2}$
Net Income (NI)

$\mathrm{NI}=$ Gross Income - Cost $\mathrm{C}_{2}$

Returns to Management (RM)

$\mathrm{RM}=$ Gross Income - Cost $\mathrm{C}_{3}$

Returns per Rupee (RPR)

$\mathrm{RPR}=\frac{\text { Gross Income per } \mathrm{Ha}}{\text { Cost } \mathrm{C}_{2} \text { per } \mathrm{Ha}}$

Similar Farm Efficiency Measures were also practiced by Ramakrishna et al., during 2017. Besides these, one would be interested in assessing the productivity turned to the usage of Labour and Fertilizer used as the main input becomes important.

\section{Labour productivity}

Labour productivity measures the amount of product and services manufactured by one hour of labour. It was calculated by using the following formula:

Labour Productivity $=$ Yield $(\mathrm{Kgs}) /$ Amount of Human Laborers Used (Man Days)

\section{Fertilizer productivity}

Fertilizer productivity measures the amount of goods and services produced by one unit of fertilizer. It was calculated by using the following formula:

Fertilizer Productivity = Yield $(\mathrm{Kgs}) /$ Amount of Fertilizers used (Kgs.)

With this background information of the methodological approach, the data were analyzed and the results are appropriately interpreted and discussed in the results section. 


\section{Results and Discussion}

Economic appraisal of different varieties of Banana are assessed on the following lines. They are

Costs Incurred and Returns Realized from Different Varieties of Banana

Type of Costs Involved in Establishment of Banana Plantations

Efficiency Measures of Banana Farms

\section{Costs incurred and returns realized from Yelakki variety of banana}

Yelakki variety of Banana is small to medium sized tasty fruit capable of providing moderate yield. It is a hard variety and it performs well even in complete shade suited for planting in coconut gardens as intercrop. The pulp of the fruit is so tasty and appears in light orange yellow color.

The plant resembles that of Red Banana with red colored pseudo stem. It is capable of tolerating leaf spot and widely cultivated in Tiruchirappalli District. The fruit is much attractive one to the consumers because of its rich taste and a mild aroma. The costs and returns realized from Yelakki variety of Banana is analyzed and the results are presented in Table 2.

Table 2 revealed that the total cost of cultivating the Yelakki variety of Banana was arrived at Rs 4.07 Lakhs. Among the total costs, the material input required for establishment of Yelakki variety of Banana was accounted for 28.51 per cent to the total costs. The total variable cost consumed by the Yelakki variety of Banana plantation per ha accounted for around 50 per cent of the total costs. From that one could infer that the Banana plantation is capable of consuming higher cost for its establishment. The small farmers may find many difficulties in investment on commercial plantations like Banana.

The Gross Return realized from the Yelakki variety of Banana Plantation is arrived at Rs 6.93 lakhs and on deducting the Cost C2, the net return was arrived at Rs. 2.67 lakhs. The yield of Yelakki variety of Banana per ha was arrived at $31487 \mathrm{kgs}$ or 31.50 tonnes per ha. When compared to the yield of other varieties, Yelakki is capable of providing lesser yield but attracts considerable price per $\mathrm{kg}$ of Yelakki variety of Banana in the open market.

The cost of production of One $\mathrm{Kg}$ of Yelakki variety of Banana was arrived at Rs. 13.52 and it is capable of fetching an attractive price of Rs 22 per $\mathrm{kg}$ of Yelakki variety and hence the farmer could generate a net return of Rupees 8.50 per $\mathrm{Kg}$ of Banana. Output is referred to as gross return realized per ha and input is the cost that was arrived in Cost C2. When one could examine the Output-Input Ratio, it was arrived at 1.63 revealed that the Yelakki variety of Banana could generate Rs. 1.63 for one rupee of investment. Though the market demand is almost stable for this variety, a group approach to marketing by establishing a Farmer Producer Company is warranted to have collective bargaining of Price per unit of Yelakki variety of Banana.

Since Tiruchirappalli farmers are not facing any constraint related to the water input while their counterparts in other districts were much demanding for the water input, the farmers were reluctant to change their traditional way of harnessing certain inputs to get the yield of Banana and hence the Department of Horticulture and Agriculture should pay much attention on Changing the attitude of the farmers by approaching some management institutions on giving a psychological aspects of change management so that they will be willingly take up the modern practices of 
managing the commercial plantations in their soils.

\section{Costs Incurred and Returns Realized from Nendran Variety of Banana}

Nendran Variety of Banana is widely distributed in all Banana growing areas of Kerala, Karnataka and Tamil Nadu including Pondicherry. It is a fairly tall and robust plant weighing a bunch of 18 to $21 \mathrm{Kgs}$. The fruits are very bold, knobbed and pale green in Colour. It is widely used for Chips making in Kerala, Karnataka and Tamil Nadu and the Chips are exclusively fried in Coconut oil adds taste to the taste buds of the human and hence it has attractive market in all southern states. The Chips are drawn from partially ripen fruits and fully ripen fruits which have different taste while adding value in the coconut oil. Apart from its culinary uses, pith is highly relished as a vegetable with lot of medicinal properties and hence it has great demand. Because of great demand, the farmers in Tiruchirappalli has also started cultivating the fruits in their holdings. In the sample farms, the Nendran variety of Banana has occupied an area of 85 ha and hence the costs and returns are analyzed separately and the results are presented in Table 3.

Table 3 revealed that the total cost of cultivating the Nendran variety of Banana was arrived at Rs 4.16 Lakhs. Among the total costs, the material input required for establishment of Nendran variety of Banana was accounted for 28 per cent to the total costs. The total variable cost consumed by the Nendran variety of Banana plantation per ha is accounted for around 79 per cent of the total costs. From that one could infer that the Banana plantation is capable of consuming higher cost for its establishment. When compared to the total cost incurred in respect of Yelakki variety, Nendran is capable of consuming lesser cost and hence the semi- medium, medium and large category of farms can take up this venture.

The Gross Return realized from the Nendran variety of Banana Plantation was arrived at Rs 7.69 lakhs and on deducting the Cost C2 incurred in cultivation, the net return was arrived at Rs. 3.30 lakhs which is marginally high when compared to the net return obtained from Yelakki variety of Banana. The yield of Nendran variety of Banana per ha was arrived at $28487 \mathrm{kgs}$ or 28.49 tonnes per ha. When compared to the yield of other varieties, Nendran is capable of providing lesser yield but attracts considerable price per $\mathrm{kg}$ of Nendran Banana in the open market. The cost of production of One Kg of Nendran variety of Banana was arrived at Rs. 15.42 and it is capable of fetching an attractive price of Rs 27 per $\mathrm{kg}$ of Nendran which is marginally high when compared to the price of Yelakki variety and hence the farmer could generate a net return of Rupees 12 per $\mathrm{Kg}$ of Banana. Though the market demand is almost stable for this variety, a group approach to marketing by establishing a Farmer Producer Company can be thought off to have collective bargaining of Price per unit of Nendran variety of Banana.

When compared to the costs and returns realized in respect of Nendran with that of Yelakki, there were only marginal difference and these two varieties were almost having a steady market demand and capable of fetching higher price per unit.

\section{Costs incurred and returns realized from Poovan variety of banana}

Poovan variety of Banana is an important commercial variety of Tamil Nadu produced year round in large quantities. Plants grow tall and vigorous during its vegetative stage. The Bunch of Poovan variety are large and weighs up to $25 \mathrm{kgs}$. It may contain up to 20 fingers. 
Atotal of 200 or more fruits per bunch is normally visible. The fruits are medium in size, cylindrical, pronounced nipple will be there. The skin of the fruits are so thin, bright yellow in color and peels off easily. The pulp of the fruit is soft, juicy, acid-sweet taste and good flavor when it ripened. The duration of the crop is ranging between 11 to 14 months. It is highly susceptible to Banana Mosaic Virus and Banana Streak Virus which causes reduction in the yield. However, the area under Poovan variety of Banana is considerably higher when compared to all other varieties. It was cultivated in an area of 186 ha in the sample farms. In this context, the costs incurred and the return realized details are analyzed and the results are presented in Table 4.

Table 4 revealed that the total cost of cultivating the Poovan variety of Banana was arrived at Rs 3.55 Lakhs. Among the total costs, the material input required for establishment of Poovan variety of Banana was accounted for 27 per cent to the total costs. The total variable cost consumed by the Poovan variety of Banana plantation per ha is accounted for around 75 per cent of the total costs. From that one could infer that the Banana plantation is capable of consuming higher cost for its establishment. When compared to the total cost incurred in respect of Yelakki and Nendran varieties, Poovan is capable of consuming lesser cost and hence the semi-medium, medium and large category of farms can take up this venture.

The Gross Return realized from the Poovan variety of Banana Plantation was arrived at Rs 4.86 lakhs and on deducting the Cost C2 incurred in cultivation, the net return was arrived at Rs. 1.63 lakhs which is comparatively low when compared to the net return obtained from Yelakki and Nendran varieties of Banana. The yield of Poovan variety of Banana per ha was arrived at 29487 kgs or 29.48 tonnes per ha. When compared to the yield of other varieties, Poovan is capable of providing better yield next to Yelakki variety but attracts low market price per kg of Poovan Banana in the open market. The cost of production of One Kg of Poovan variety of Banana was arrived at Rs. 11 and it is capable of fetching low procurement price which is arrived at Rs 16.50 per $\mathrm{kg}$ of Poovan which is very low when compared to the price of Yelakki and Nendran varieties and hence the farmer could generate a net return of Rupees 5.50 per $\mathrm{Kg}$ of Banana. Though the market demand is uncertain and fluctuating for this variety, a value addition could be thought off after establishing the farmer producer companies.

When compared to the costs and returns realized in respect of Poovan with that of Yelakki and Nendran, there are very low returns from Poovan variety. But the area under this variety is found to be considerably high and the variety is being preferred by the traders and farmers because of Banana leaves and for fruit purpose and hence Poovan variety may be given best possible value addition so as to enhance its market potential and make the market steady for the Poovan variety of Banana. According to Nandini (2017), Poovan variety is enriched with the highest amount of protein which is arrived at 1.37 grams per one hundred gram of fruit and was significantly different from other varieties and hence the consumption of Poovan should be encouraged among the children and hence it has positive attribute to cultivate in higher area.

\section{Costs incurred and returns realized from Rasthali variety of banana}

Rasthali is the most preferred variety among the traders and the consumers because of sweetness. It is a delicious variety grown mostly in Erode and Tiruchirappalli Districts 
of Tamil Nadu. Poovan variety commands tall suckers which is yellowish green with brownish blotches, reddish margins of petiole and leaf sheath. The harvested bunch of Rasthali weighs between 15 to $20 \mathrm{Kgs}$ in which the number of hands will be of 8 to 16 and the number of fruits per bunch will be around 60 to 80 fruits. The fruits are medium sized, cylindrical to spindle shaped, weak pedicel, thin skin and peels easily. The colour of the fruit is ivory yellow and produces pleasant aroma. The demerits of the variety is it is susceptible to Panama wilt, formation of hard lump in pulp and easy dropping of fruits from the bunch when it fully ripens. The duration of the crop will be ranging between 14 to 15 months. Rasthali is the variety cultivated in very small area. In the sample farms, it is cultivated only around 50 ha. In this context, it is important to document the costs incurred and the returns realized details and hence these results are presented in Table 5 .

Table 5 revealed that the total cost of cultivatingthe Rasthali variety of Banana was arrived at Rs 4.01 Lakhs. Among the total costs, the material input required for establishment of Rasthali variety of Banana was accounted for 28 per cent to the total costs. In terms of absolute figures, Material cost for Rasthali found to be marginally higher than the Poovan variety. The total variable cost consumed by the Rasthali variety of Banana plantation per ha is accounted for around 76.19 per cent of the total costs. From that one could infer that the Banana plantation is capable of consuming higher cost for its establishment. When compared to the total cost incurred in respect of Yelakki, Nendran and Poovan varieties, Rasthali is capable of consuming higher cost than the Poovan variety and hence the semimedium, medium and large category of farms can take up this venture.
The Gross Return realized from the Rasthali variety of Banana Plantation was arrived at Rs 5.90 lakhs and on deducting the Cost A2 incurred in cultivation, the net return was arrived at Rs. 1.37 lakhs which is comparatively higher when compared to the net return obtained from Poovan variety of Banana. The yield of Rasthali variety of Banana per ha was arrived at $32787 \mathrm{kgs}$ or 32.79 tonnes per ha. When compared to the yield of other varieties, Rasthali is capable of providing better yield but attracts optimum market price per $\mathrm{kg}$ of Rasthali Banana in the open market. The cost of production of One $\mathrm{Kg}$ of Rasthali variety of Banana was arrived at Rs. 13.83 and it is capable of fetching low procurement price which is arrived at Rs 18 per $\mathrm{kg}$ of Rasthali which is comparatively higher when compared to the price of Poovan variety and hence the farmer could generate a net return of Rupees 4 per $\mathrm{Kg}$ of Banana. The low price prevailed for Rasthali variety was mainly due to withering of fruits from its fingers immediately after ripening and hence consumer acceptance in that case becomes poor and hence the share in the retail price is poor to the farmers. Though the market demand is stable for this variety, higher support price could be realized on establishing the farmer producer companies.

When compared to the costs and returns realized in respect of Rasthali with that of Yelakki, Nendran and Poovan, there are considerable returns from Poovan variety. But the area under this variety is found to be much low and the variety is being preferred by the traders and farmers because of its taste and aroma and hence Rasthali variety may be given a special emphasis so as to enhance its area under this variety and make the market steady for the Rasthali variety of Banana.

To sum up, among the varieties, Yelakki and Nendran are found to be the sweetest varieties which are capable of providing higher yield 
and net return over the total cost. Poovan is the variety which is capable of yielding more, its market price is very low and hence value addition possibilities could be thought off besides promoting the Poovan for its better nutritional value among the Children's diet.

\section{Types of costs incurred in different} varieties of banana cultivation

According to Commission on Agricultural Costs and Prices in Government of India, the Cost categories are classified as Cost $\mathrm{A}_{1}$, Cost $A_{2}$, Cost $B_{1}$, Cost $B_{2}$, Cost $C_{1}$, Cost $C_{2}$ and Cost $C_{3}$. How these costs are arrived and spread between different varieties of Banana are an important question and hence these details are analyzed and the results are presented in Table 6.

Table 6 revealed the status of cost involvement in establishing Banana plantation in one ha of land. When one could examine the Cost $A_{1}$, it is too low in respect of Poovan variety which is arrived at 2.68 lakhs. Highest Cost $A_{1}$ was incurred in respect of Nendran variety of Banana. The average of Cost A1 incurred in all the varieties is arrived at Rs. 3.05 lakhs. Similar cost involvement is also reported by Ramakrishna et al., during 2017.

When one could examine the Cost $A_{2}$, it has also become the lowest in respect of Poovan variety which stood at Rs 2.68lakhs. The highest Cost $A_{2}$ was incurred in respect of Nendran variety of Banana. Similar results are obtained in respect of Cost $\mathrm{B}_{1}$, Cost $\mathrm{B}_{2}$, Cost $\mathrm{C}_{1}, \operatorname{Cost} \mathrm{C}_{2}$ and Cost $\mathrm{C}_{3}$.

All these costs are comparatively low in respect of Poovan variety when compared to all other varieties followed by Rasthali and Nendran varieties which are commanding the highest cost among all the varieties of Banana. From that one could infer that the establishment of Nendran and Rasthali varieties commands higher cost and the Poovan variety is capable of consuming the lowest cost.

\section{Efficiency measures in banana farms}

A measuring stick is necessary to provide guides and standard for appraising accuracy of decisions regarding the use of resources available in the farm. One method of production is said to be more efficient than the other when it yields greater valuable output per unit of valuable input. From an economic perspective, efficiency is desirable. Efficiency can be related to the operation of farm business as a whole, any individual phase of the business, line of production, the use of various factors of production in the farm or any single input and its contribution to the output like fertilizer or labour and or both.

Various efficiency measures, therefore, need to be developed to express technical efficiency in various farm business and to relate these to the financial success. One such measures are analyzed and the results are presented in Table 7.

Table 7 revealed that the gross return realizable in per ha plantation of Banana is in favour of Nendran, Yelakki and Rasthali varieties as these varieties are capable of fetching 7.69 lakhs, 6.93 lakhs and 5.90 lakhs respectively. ThePoovan variety is able to generate only around 4.87 lakhs as its Gross return. The low return from Poovan variety when compared to their counterparts is mainly because of low procurement price from the farmers and in the market, it commands less price and preference over other varieties.

The Return over Variable Cost (RVC) is favourable in respect of Nendran variety followed by Yelakki variety of Banana which 
are respectively able to generate Rs. 4.41 lakhs and 3.74 lakhs. The Return over Variable Cost is very low in respect of Poovan variety of Banana. However, the average variable cost is arrived at Rs. 3.30 lakhs which is a considerable income to the farmers. But the sample farm households should think of alternative variety like Yelakki or Nendran or Rasthali in the place of Poovan variety for generating higher income.

Table.1 Measurement of variables

\begin{tabular}{|c|c|}
\hline Name of the Variables & Measurement of Variables \\
\hline Seedlings or Suckers & $\begin{array}{l}\text { Commercial farmers have obtained the Suckers / Corms / Tissue culture plantlets } \\
\text { at local or distant place based on the prevailing market price. The actual price paid } \\
\text { by the farmers per unit was used. }\end{array}$ \\
\hline Human Labour & $\begin{array}{l}\text { The total number of male and female laborers used are measured in terms of } \\
\text { number of man days. The labour cost of family labour and hired labour was } \\
\text { converted to common physical unit ( } 1 \text { Man days }=6 \text { working hours). The family } \\
\text { labour was considered separately and added to the hired labour to calculate the } \\
\text { total labour requirement. }\end{array}$ \\
\hline Machineries & $\begin{array}{l}\text { The total machineries used was measured in terms of machine hours and the price paid } \\
\text { per machine hour was taken into account. }\end{array}$ \\
\hline $\begin{array}{r}\text { Organic Manures and } \\
\text { Inorganic Fertilizers }\end{array}$ & $\begin{array}{l}\text { The data of farm yard manure produced at farm level or neighbor farms were } \\
\text { valued at prevailing market price in kgs and chemical fertilizers of } \mathrm{N}, \mathrm{P}, \mathrm{K} \text { were } \\
\text { valued at actual procurement price paid by the farmers per kg of fertilizers }\end{array}$ \\
\hline Weeding and Spraying & $\begin{array}{l}\text { The total number of laborers needed per weeding and the labour value was } \\
\text { measured in terms of Man days and spraying were measured in terms of number of } \\
\text { spray multiplied by cost involved per spray. }\end{array}$ \\
\hline $\begin{array}{r}\text { Interest on Working } \\
\text { Capital }\end{array}$ & $\begin{array}{l}\text { Components included in the working capital were cost of human labour, manures, } \\
\text { fertilizers, and weeding. Interest on working capital was computed at the rate of seven } \\
\text { per cent per annum, which was charged by commercial bank for short-term loans. }\end{array}$ \\
\hline Interest on Fixed Capital & $\begin{array}{l}\text { Interest on fixed capital was computed at twelve per cent, which is the interest } \\
\text { charged for investment loans sanctioned by commercial banks in the study area. }\end{array}$ \\
\hline $\begin{array}{r}\text { Rental Value of Owned } \\
\text { Land }\end{array}$ & $\begin{array}{l}\text { It refers to the part of payment made by a tenant for the use of land per annum. } \\
\text { The contribution of land towards the crop enterprise was accounted for based on } \\
\text { the rental value of land prevalent in the area. }\end{array}$ \\
\hline Land Revenue & $\begin{array}{l}\text { Land revenue was taken at the rates levied by the government. Land revenue paid } \\
\text { by the farmers during the current year was considered for this study. }\end{array}$ \\
\hline Yield & $\begin{array}{l}\text { The total yield of Banana bunches obtained by the farmers was expressed in terms } \\
\text { of tonnes per ha. }\end{array}$ \\
\hline Gross Return & $\begin{array}{l}\text { The gross returns per ha was calculated based on what the sample farmers actually } \\
\text { realized as yield multiplied by the market price per unit of the produce. }\end{array}$ \\
\hline Net Returns & The net return was calculated by subtracting gross returns from the Cost $\mathrm{C} 2$. \\
\hline Depreciation & $\begin{array}{l}\text { Depreciation of farm buildings can be financed to the independent venture in } \\
\text { percentage to the total area under an enterprise in case the building is used for } \\
\text { different enterprises. However, if the building was used for single enterprise, the } \\
\text { entire depreciation was charged to that particular enterprise } \\
\text { As in case of farm buildings, the depreciation or minor repairs can be charged to } \\
\text { individual enterprise in proportion to the area under a given enterprise. Possibly, } \\
\text { time consumed on separate venture by a given machine / tool and implements } \\
\text { formed the basis for charging depreciation. }\end{array}$ \\
\hline
\end{tabular}


Table.2 Costs and returns in cultivation of Yelakki variety of banana

\begin{tabular}{|c|c|c|c|c|}
\hline Sl. No & Particulars of Cost & Inputs / ha & $\begin{array}{l}\text { Amount in } \\
\text { Rs / ha }\end{array}$ & $\begin{array}{c}\text { Percentage to } \\
\text { Total }\end{array}$ \\
\hline $\mathbf{A}$ & Material Cost & & & \\
\hline 01 & Number of Suckers & 2415 & 20528 & 05.05 \\
\hline 02 & Farm Yard Manure in Kgs & 7016 & 9472 & 02.33 \\
\hline $\mathbf{0 3}$ & Quantity of Weedicide (Litres) & 04.87 & 1460 & 00.36 \\
\hline 04 & Sucker Treatment & 21.54 & 1793 & 00.44 \\
\hline 05 & Quantity of Pesticide in Litres & 01.79 & 1978 & 00.49 \\
\hline 06 & $\begin{array}{l}\text { Number of Casuarina Pole for } \\
\text { Propping (Life of Poles will be for } \\
5 \text { years - Cost per Annum) }\end{array}$ & 2419 & 25230 & 06.20 \\
\hline 07 & Quantum of Micronutrient (Kgs) & 391.05 & 6890 & 01.69 \\
\hline 08 & Quantum of Nitrogen (Kgs) & 715.23 & 6888 & 01.69 \\
\hline 09 & Quantum of Phosphorous in Kgs & 658.25 & 13079 & 03.22 \\
\hline 10 & Quantum of Potassium in Kgs & 1365.28 & 21845 & 05.37 \\
\hline 11 & Quantum of Bio-fertilizers in Kgs & 36.52 & 530 & 00.13 \\
\hline \multirow[t]{2}{*}{12} & Miscellaneous Inputs & 87 & 6273 & 01.54 \\
\hline & Sub Total (A) & & 115964 & 28.51 \\
\hline B & Operational Cost & & & \\
\hline 13 & Land Preparation - Machine Hours & 09.18 & 7344 & 01.81 \\
\hline 14 & Formation of Bunds - Men Labour & 47.57 & 18969 & 04.66 \\
\hline 15 & Drenching - Men Labour & 54.13 & 23010 & 05.66 \\
\hline 16 & Planting of Suckers - Men Labour & 28.16 & 8758 & 02.15 \\
\hline 17 & Planting of Suckers - Women & 11.69 & 1528 & 00.38 \\
\hline 18 & Application of Fertilizers - Women & 09 & 1964 & 00.48 \\
\hline 19 & First Application & 11.56 & 2265 & 00.56 \\
\hline 20 & Second Application & 12.65 & 2459 & 00.60 \\
\hline 21 & Third Application & 12.89 & 2529 & 00.62 \\
\hline 22 & De-suckering - Men Labour & 18.24 & 7263 & 01.79 \\
\hline 23 & Drenching - Men Labour & 41.65 & 15734 & 03.87 \\
\hline 24 & Irrigation - Men Labour & 17.36 & 6946 & 01.71 \\
\hline 25 & Weeding Men + Women Labour & 06.19 & 1351 & 00.33 \\
\hline 26 & $\begin{array}{l}\text { Weedicide Application - } \\
\text { Men Labour }\end{array}$ & 64.23 & 25692 & 06.32 \\
\hline 27 & Weedicide - Women Labour & 52.36 & 10076 & 02.48 \\
\hline 28 & Pesticide Spray - Men Labour & 4.89 & 1956 & 00.48 \\
\hline 29 & Propping - Men Labour & 21.69 & 8695 & 02.14 \\
\hline 30 & Propping - Women Labour & 31.68 & 6375 & 01.57 \\
\hline 31 & Bunch Spray for Maturity & 03.12 & 858 & 00.21 \\
\hline 32 & Harvesting of Banana - Men Labour & 58.29 & 23315 & 05.73 \\
\hline 33 & Miscellaneous Charges & & 4568 & 01.12 \\
\hline \multirow[t]{2}{*}{34} & Interest on Working Capital @ 12\% & & 21798 & 05.36 \\
\hline & Sub Total $(\mathrm{B})$ & & 203450 & 50.01 \\
\hline $\mathbf{C}$ & Total Variable Cost $(A+B)$ & & 319415 & 78.52 \\
\hline D & Total Fixed Cost (D) & & 87372 & 21.48 \\
\hline
\end{tabular}




\begin{tabular}{|c|l|c|c|c|}
\hline $\mathbf{3 5}$ & Rental Value of Owned Land & 57964 & 14.25 \\
\hline $\mathbf{3 6}$ & Rent Paid for Leased-in Land & & 19687 & 04.84 \\
\hline $\mathbf{3 7}$ & Land Revenue & & 0360 & 00.09 \\
\hline $\mathbf{3 8}$ & Interest on Fixed Capital @ 12\% & & 9361 & 02.30 \\
\hline $\mathbf{E}$ & $\begin{array}{l}\text { Total Cost of Cultivation } \\
\text { (A+B+C+D) }\end{array}$ & & $\mathbf{4 0 6 7 8 7 . 0 0}$ & $\mathbf{1 0 0 . 0 0}$ \\
\hline $\mathbf{3 9}$ & Yield of Banana in Kgs per Ha & 31487 & 692714.00 & \\
\hline $\mathbf{4 0}$ & Gross Return Realized in Rupees & & 692714.00 & \\
\hline $\mathbf{4 1}$ & Net Return Realized in Rupees/Ha & & $\mathbf{2 6 7 0 7 5 . 0 0}$ & \\
\hline $\mathbf{4 2}$ & Output - Input Ratio & $\mathbf{0 1 . 6 3}$ & \\
\hline Cost of Production per Kg of Banana & & $\mathbf{1 3 . 5 2}$ & \\
\hline
\end{tabular}

Table.3 Costs and returns in cultivation of Nendran variety of banana

\begin{tabular}{|c|c|c|c|c|}
\hline $\begin{array}{l}\text { Sl. } \\
\text { No }\end{array}$ & Particulars of Cost & Inputs / ha & Amount in Rs / ha & $\begin{array}{c}\text { Percentage } \\
\text { to Total }\end{array}$ \\
\hline $\mathbf{A}$ & Material Cost & & & \\
\hline 01 & Number of Suckers & 2315 & 21993 & 05.28 \\
\hline $\mathbf{0 2}$ & Farm Yard Manure in Kgs & 7016 & 9472 & 02.28 \\
\hline $\mathbf{0 3}$ & Quantity of Weedicide (Litres) & 04.87 & 1460 & 00.35 \\
\hline 04 & Sucker Treatment & 24.54 & 2042 & 00.49 \\
\hline 05 & Quantity of Pesticide in Litres & 01.90 & 2100 & 00.50 \\
\hline 06 & $\begin{array}{l}\text { Number of Casuarina Pole for Propping } \\
\text { (Life of Poles will be for } 5 \text { years - Cost } \\
\text { per Annum) }\end{array}$ & 2319 & 24187 & 05.81 \\
\hline 07 & Quantum of Micronutrient (Kgs) & 401 & 7067 & 01.70 \\
\hline 08 & Quantum of Nitrogen (Kgs) & 715 & 6888 & 01.65 \\
\hline 09 & Quantum of Phosphorous in Kgs & 658 & 13079 & 03.14 \\
\hline 10 & Quantum of Potassium in Kgs & 1465 & 23444 & 05.63 \\
\hline 11 & Quantum of Bio-fertilizers & 38.52 & 559 & 00.13 \\
\hline \multirow{2}{*}{12} & Miscellaneous Inputs like Fuel & 67 & 4831 & 01.16 \\
\hline & Sub Total $(\mathrm{A})$ & & 117121 & 28.13 \\
\hline B & Operational Cost & & & \\
\hline 13 & Land Preparation - Machine Hours & 09.18 & 7344 & 01.76 \\
\hline 14 & Formation of Bunds - Men Labour & 47.57 & 18969 & 04.56 \\
\hline 15 & Drenching - Men Labour & 54.13 & 23010 & 05.53 \\
\hline 16 & Planting of Suckers - Men Labour & 28.16 & 8758 & 02.10 \\
\hline 17 & Planting of Suckers - Women & 11.69 & 1528 & 00.37 \\
\hline 18 & Application of Fertilizers - Women & 09.12 & 1964 & 00.47 \\
\hline 19 & First Application & 12.56 & 2460 & 00.59 \\
\hline 20 & Second Application & 12.65 & 2459 & 00.59 \\
\hline 21 & Third Application & 13.89 & 2726 & 00.65 \\
\hline 22 & De-suckering - Men Labour & 18.24 & 7263 & 01.74 \\
\hline 23 & Drenching - Men Labour & 41.65 & 15734 & 03.78 \\
\hline 24 & Irrigation - Men Labour & 17.36 & 6946 & 01.67 \\
\hline 25 & Weeding Men + Women Labour & 06.19 & 1351 & 00.32 \\
\hline 26 & Weedicide Application - Men Labour & 64.23 & 25692 & 06.17 \\
\hline
\end{tabular}




\begin{tabular}{|c|l|c|c|c|}
\hline $\mathbf{2 7}$ & Weedicide - Women Labour & 52.36 & 10076 & 02.42 \\
\hline $\mathbf{2 8}$ & Pesticide Spray - Men Labour & 04.89 & 1956 & 00.47 \\
\hline & Propping - Men Labour & 21.69 & 8695 & 02.09 \\
\hline & Propping - Women Labour & 31.68 & 6375 & 01.53 \\
\hline $\mathbf{2 9}$ & Bunch Spray for Maturity & 05.12 & 1408 & 00.34 \\
\hline $\mathbf{3 0}$ & Harvesting of Banana - Men Labour & 62.29 & 28652 & 06.88 \\
\hline $\mathbf{3 1}$ & Miscellaneous Charges & & 4568 & 01.10 \\
\hline $\mathbf{3 2}$ & Interest on Working Capital @ 12\% & & 22552 & 05.42 \\
\hline & Sub Total (B) & & $\mathbf{2 1 0 4 8 3}$ & $\mathbf{5 0 . 5 6}$ \\
\hline $\mathbf{C}$ & Total Variable Cost (A + B) & & $\mathbf{3 2 7 6 0 4}$ & $\mathbf{7 8 . 6 9}$ \\
\hline $\mathbf{D}$ & Total Fixed Cost (D) & & $\mathbf{8 8 7 1 6}$ & $\mathbf{2 1 . 3 1}$ \\
\hline $\mathbf{3 3}$ & Rental Value of Owned Land & & 0460 & 04.75 \\
\hline $\mathbf{3 4}$ & Rent Paid for Leased-in Land & & 9505 & 00.11 \\
\hline $\mathbf{3 5}$ & Land Revenue & $\mathbf{4 1 6 3 2 0 . 0 0}$ & $\mathbf{1 0 0 . 0 0}$ \\
\hline $\mathbf{3 6}$ & Interest on Fixed Capital @ 12\% & 769149 & \\
\hline $\mathbf{E}$ & Total Cost of Cultivation (A+B+C+D) & & 769149 & \\
\hline $\mathbf{3 7}$ & Yield of Banana in Kgs per Ha & 28487 & $\mathbf{3 2 9 8 5 9 . 0 0}$ & \\
\hline $\mathbf{3 8}$ & Gross Return Realized in Rupees & & $\mathbf{1 5 . 4 2}$ & \\
\hline $\mathbf{3 9}$ & Net Return Realized in Rupees/Ha & & $\mathbf{0 1 . 7 5}$ & \\
\hline & Cost of Production per Kg of Banana & & & \\
\hline & & & \\
\hline
\end{tabular}

Table.4 Costs and returns in cultivation of Poovan variety of banana

\begin{tabular}{|c|c|c|c|c|}
\hline $\begin{array}{l}\text { Sl. } \\
\text { No }\end{array}$ & Particulars of Cost & $\begin{array}{l}\text { Inputs/ } \\
\text { ha }\end{array}$ & $\begin{array}{l}\text { Amount in } \\
\text { Rs / ha }\end{array}$ & $\begin{array}{l}\text { Percentage } \\
\text { to Total }\end{array}$ \\
\hline $\mathbf{A}$ & Material Cost & & & \\
\hline 01 & Number of Suckers & 2016 & 17128 & 04.82 \\
\hline 02 & Farm Yard Manure in Kgs & 5916 & 7987 & 02.25 \\
\hline 03 & Quantity of Weedicide (Litres) & 04.17 & 1250 & 00.35 \\
\hline 04 & Sucker Treatment & 17.54 & 1460 & 00.41 \\
\hline 05 & Quantity of Pesticide in Litres & 01.49 & 1647 & 00.46 \\
\hline 06 & $\begin{array}{l}\text { Number of Casuarina Pole for Propping (Life } \\
\text { of Poles will be for } 5 \text { years - Cost per Annum) }\end{array}$ & 2019 & 21058 & 05.93 \\
\hline 07 & Quantum of Micronutrient (Kgs) & 371 & 6538 & 01.84 \\
\hline 08 & Quantum of Nitrogen (Kgs) & 615 & 5925 & 01.67 \\
\hline 09 & Quantum of Phosphorous in Kgs & 608 & 12086 & 03.40 \\
\hline 10 & Quantum of Potassium in Kgs & 1065 & 17044 & 04.80 \\
\hline 11 & Quantum of Bio-fertilizers & 26.52 & 384.54 & 00.11 \\
\hline \multirow[t]{2}{*}{12} & Miscellaneous Inputs like Fuel & 57 & 4110 & 01.16 \\
\hline & Sub Total $(\mathrm{A})$ & & 96616 & 27.20 \\
\hline B & Operational Cost & & & \\
\hline 13 & Land Preparation - Machine Hours & 7.18 & 5744 & 01.62 \\
\hline 14 & Formation of Bunds - Men Labour & 46.57 & 18570 & 05.23 \\
\hline 15 & Drenching - Men Labour & 49.13 & 20885 & 05.88 \\
\hline 16 & Planting of Suckers - Men Labour & 25.16 & 7825 & 02.20 \\
\hline 17 & Planting of Suckers - Women & 15.69 & 2051 & 00.58 \\
\hline
\end{tabular}




\begin{tabular}{|l|l|c|c|c|}
\hline $\mathbf{1 8}$ & Application of Fertilizers - Women & 10.12 & 2179 & 00.61 \\
\hline $\mathbf{1 9}$ & First Application & 11.56 & 2265 & 00.64 \\
\hline $\mathbf{2 0}$ & Second Application & 09.65 & 1875 & 00.53 \\
\hline $\mathbf{2 1}$ & Third Application & 09.89 & 1941 & 00.55 \\
\hline $\mathbf{2 2}$ & De-suckering - Men Labour & 18.24 & 7263 & 02.04 \\
\hline $\mathbf{2 3}$ & Drenching - Men Labour & 31.65 & 11956 & 03.37 \\
\hline $\mathbf{2 4}$ & Irrigation - Men Labour & 13.36 & 5345 & 01.51 \\
\hline $\mathbf{2 5}$ & Weeding Men + Women Labour & 06.19 & 1351 & 00.38 \\
\hline $\mathbf{2 6}$ & Weedicide Application - Men Labour & 44.23 & 17692 & 04.98 \\
\hline $\mathbf{2 7}$ & Weedicide - Women Labour & 32.36 & 6227 & 01.75 \\
\hline $\mathbf{2 8}$ & Pesticide Spray - Men Labour & 04.89 & 1956 & 00.55 \\
\hline $\mathbf{2 9}$ & Propping - Men Labour & 21.69 & 8695 & 02.45 \\
\hline $\mathbf{3 0}$ & Propping - Women Labour & 21.67 & 4362 & 01.23 \\
\hline $\mathbf{3 1}$ & Bunch Spray for Maturity & 03.12 & 858 & 00.24 \\
\hline $\mathbf{3 2}$ & Harvesting of Banana - Men Labour & 48.29 & 19315 & 05.44 \\
\hline $\mathbf{3 3}$ & Miscellaneous Charges & & 4568 & 01.29 \\
\hline $\mathbf{3 4}$ & Interest on Fixed Capital at 12\% & & 18351 & 05.17 \\
\hline & Sub Total (B) & & $\mathbf{1 7 1 2 7 4}$ & $\mathbf{4 8 . 2 1}$ \\
\hline C & Total Variable Cost (A + B) Cost A1 & & $\mathbf{2 6 7 8 8 9}$ & $\mathbf{7 5 . 4 1}$ \\
\hline D & Total Fixed Cost (D) & & $\mathbf{5 7 9 6 4}$ & $\mathbf{1 6 . 3 2}$ \\
\hline $\mathbf{3 3}$ & Rental Value of Owned Land & & $\mathbf{1 9 6 8 7}$ & 05.54 \\
\hline $\mathbf{3 4}$ & Rent Paid for Leased-in Land & & 360 & 00.10 \\
\hline $\mathbf{3 5}$ & Land Revenue & & 9361 & 02.64 \\
\hline $\mathbf{3 6}$ & Interest on Fixed Capital @ 12\% & $\mathbf{3 5 5 2 6 2}$ & $\mathbf{1 0 0 . 0 0}$ \\
\hline $\mathbf{E}$ & Total Cost of Cultivation (A+B+C+D) & 486535 & \\
\hline $\mathbf{3 7}$ & Yield of Banana in Kgs per Ha & & $\mathbf{1 6 3 1 0 6}$ & \\
\hline $\mathbf{3 8}$ & Gross Return Realized in Rupees & & \\
\hline $\mathbf{3 9}$ & Net Return Realized in Rupees/Ha & & & \\
\hline $\mathbf{C o s t}$ of Production per Kg of Banana & & & \\
\hline Output & Input Ratio & & & \\
\hline & & & & \\
\hline
\end{tabular}

Table.5 Costs and returns in cultivation of Rasthali variety of banana

\begin{tabular}{|c|l|c|c|c|}
\hline Sl. No & \multicolumn{1}{|c|}{ Particulars of Cost } & $\begin{array}{c}\text { Inputs / } \\
\text { ha }\end{array}$ & $\begin{array}{c}\text { Amount } \\
\text { in } \\
\text { Rs / ha }\end{array}$ & $\begin{array}{c}\text { Percentage } \\
\text { to Total }\end{array}$ \\
\hline $\mathbf{A}$ & Material Cost & & & \\
\hline $\mathbf{0 1}$ & Number of Suckers & 2215 & 18828 & 04.70 \\
\hline $\mathbf{0 2}$ & Farm Yard Manure in Kgs & 6016 & 8122 & 02.03 \\
\hline $\mathbf{0 3}$ & Quantity of Weedicide (Litres) & 05.87 & 1760 & 00.44 \\
\hline $\mathbf{0 4}$ & Sucker Treatment & 20.54 & 1709 & 00.43 \\
\hline $\mathbf{0 5}$ & Quantity of Pesticide in Litres & 04.79 & 5293 & 01.32 \\
\hline $\mathbf{0 6}$ & $\begin{array}{l}\text { Number of Casuarina Pole for Propping } \\
\text { (Life of Poles will be for 5 years - Cost per }\end{array}$ & 2219 & 23144 & 05.77 \\
\hline $\mathbf{0 7}$ & $\begin{array}{l}\text { Annum) } \\
\text { Quantum of Micronutrient (Kgs) }\end{array}$ & 441.05 & 7771 & 01.94 \\
\hline
\end{tabular}




\begin{tabular}{|c|c|c|c|c|}
\hline 08 & Quantum of Nitrogen (Kgs) & 675.23 & 6502 & 01.62 \\
\hline 09 & Quantum of Phosphorous in Kgs & 628.25 & 12483 & 03.11 \\
\hline 10 & Quantum of Potassium in Kgs & 1365.28 & 21845 & 05.45 \\
\hline 11 & Quantum of Bio-fertilizers in Kgs & 41.52 & 602 & 00.15 \\
\hline \multirow{2}{*}{12} & Miscellaneous Inputs like Fuel & 67 & 4831 & 01.21 \\
\hline & Sub Total (A) & & 112890 & 28.17 \\
\hline $\mathbf{B}$ & Operational Cost & & & \\
\hline 13 & Land Preparation - Machine Hours & 09.18 & 7344 & 01.83 \\
\hline 14 & Formation of Bunds - Men Labour & 47.57 & 18968 & 04.73 \\
\hline 15 & Drenching - Men Labour & 49.13 & 20885 & 05.21 \\
\hline 16 & Planting of Suckers - Men Labour & 20.16 & 6270 & 01.56 \\
\hline 17 & Planting of Suckers - Women & 19.69 & 2573 & 00.64 \\
\hline 18 & Application of Fertilizers - Women & 10.12 & 2179 & 00.54 \\
\hline 19 & First Application & 13.56 & 2656 & 00.66 \\
\hline 20 & Second Application & 15.65 & 3042 & 00.76 \\
\hline 21 & Third Application & 16.89 & 3314 & 00.83 \\
\hline 22 & De-suckering - Men Labour & 19.24 & 7661 & 01.91 \\
\hline 23 & Drenching - Men Labour & 39.65 & 14978 & 03.74 \\
\hline 24 & Irrigation - Men Labour & 15.36 & 6146 & 01.53 \\
\hline 25 & Weeding Men + Women Labour & 15.19 & 3315 & 00.83 \\
\hline 26 & Weedicide Application - Men Labour & 54.23 & 21692 & 05.41 \\
\hline 27 & Weedicide - Women Labour & 32.36 & 6227 & 01.55 \\
\hline 28 & Pesticide Spray - Men Labour & 04.09 & 1636 & 00.41 \\
\hline 29 & Propping - Men Labour & 18.69 & 7492 & 01.87 \\
\hline 30 & Propping - Women Labour & 27.68 & 5570 & 01.39 \\
\hline 31 & Bunch Spray for Maturity & 04.02 & 1106 & 00.28 \\
\hline 32 & Harvesting of Banana - Men Labour & 59.29 & 23715 & 05.92 \\
\hline 33 & Miscellaneous Charges & & 5068 & 01.26 \\
\hline \multirow[t]{2}{*}{34} & Interest on Fixed Capital at $12 \%$ & & 20620 & 05.15 \\
\hline & Sub Total $(B)$ & & 192458 & 48.02 \\
\hline $\mathbf{C}$ & Total Variable Cost $(A+B)$ Cost A1 & & 305348 & 76.19 \\
\hline $\mathbf{D}$ & Total Fixed Cost (D) & & 95436 & 23.81 \\
\hline 35 & Rental Value of Owned Land & & 58964 & 14.71 \\
\hline 36 & Rent Paid for Leased-in Land & & 25687 & 06.41 \\
\hline 37 & Land Revenue & & 560 & 00.14 \\
\hline \multirow[t]{2}{*}{38} & Interest on Fixed Capital @ 12\% & & 10225 & 02.55 \\
\hline & Total Cost of Cultivation $(A+B+C+D)$ & & 400784 & 100.00 \\
\hline 39 & Yield of Banana in Kgs per Ha & 32787 & 590166 & \\
\hline 40 & Gross Return Realized in Rupees & & 590166 & \\
\hline 41 & Net Return Realized in Rupees/Ha & & 136711 & \\
\hline \multicolumn{2}{|c|}{ Cost of Production per $\mathrm{Kg}$ of Banana } & & 13.83 & \\
\hline \multicolumn{2}{|c|}{ Output - Input Ratio } & & 01.30 & \\
\hline
\end{tabular}


Table.6 Types of costs incurred in different varieties of banana cultivation

\begin{tabular}{|c|l|c|c|c|c|c|}
\hline \multirow{2}{*}{ Sl. No } & \multirow{2}{*}{ Cost Category } & \multicolumn{5}{|c|}{ Cost in Lakhs of Rupees (rs/ha) } \\
\cline { 3 - 7 } & & Yelakki & Nendran & Poovan & Rasthali & Average \\
\hline $\mathbf{0 1}$ & Cost $A_{1}$ & 03.19 & 03.28 & 02.68 & 03.05 & 03.05 \\
\hline $\mathbf{0 2}$ & Cost $A_{2}$ & 03.39 & 03.47 & 02.68 & 03.06 & 03.15 \\
\hline $\mathbf{0 3}$ & Cost $B_{1}$ & 03.49 & 03.57 & 02.89 & 04.01 & 03.49 \\
\hline $\mathbf{0 4}$ & Cost $B_{2}$ & 04.07 & 04.16 & 03.06 & 04.27 & 03.89 \\
\hline $\mathbf{0 5}$ & Cost $C_{1}$ & 03.68 & 03.80 & 03.04 & 04.28 & 03.70 \\
\hline $\mathbf{0 6}$ & Cost $C_{2}$ & 04.26 & 04.39 & 03.23 & 04.53 & 04.10 \\
\hline $\mathbf{0 7}$ & Cost $C_{3}$ & 04.68 & 04.83 & 03.56 & 04.98 & 04.51 \\
\hline
\end{tabular}

Table.7 Income realized from different varieties of banana

\begin{tabular}{|c|l|c|c|c|c|c|}
\hline \multirow{2}{*}{ Sl. No } & \multicolumn{1}{|c|}{ Income Measures } & \multicolumn{5}{|c|}{ Income in Lakhs of Rupees Per ha } \\
\cline { 3 - 7 } & & Yelakki & Nendran & Poovan & Rasthali & Average \\
\hline $\mathbf{0 1}$ & $\begin{array}{l}\text { Gross Return Realized } \\
\text { (Rs.in Lakhs) per ha }\end{array}$ & 06.93 & 07.69 & 04.87 & 05.90 & 06.35 \\
\hline $\mathbf{0 2}$ & $\begin{array}{l}\text { Return Over Variable } \\
\text { Cost per ha }\end{array}$ & 03.74 & 04.41 & 02.19 & 02.84 & 03.29 \\
\hline $\mathbf{0 3}$ & Farm Business Income & 03.54 & 04.22 & 02.19 & 02.84 & 03.20 \\
\hline $\mathbf{0 4}$ & Family Labour Income & 02.86 & 03.53 & 01.81 & 01.63 & 02.46 \\
\hline $\mathbf{0 5}$ & Net Income per ha & 02.67 & 03.30 & 01.64 & 01.37 & 02.24 \\
\hline $\mathbf{0 6}$ & $\begin{array}{l}\text { Returns to Management } \\
\text { per ha }\end{array}$ & 02.25 & 02.86 & 01.31 & 0.92 & 01.83 \\
\hline $\mathbf{0 7}$ & $\begin{array}{l}\text { Returns per Rupee of } \\
\text { Investment }\end{array}$ & 01.63 & 01.75 & 01.50 & 01.30 & 01.54 \\
\hline
\end{tabular}

Table.8 Details of input productivity realized in Kgs per ha

\begin{tabular}{|c|l|c|c|c|c|c|}
\hline Sl. No & \multicolumn{1}{|c|}{ Input Productivity / Ha } & Yelakki & Nendran & Poovan & Rasthali & Average \\
\hline $\mathbf{0 8}$ & Labour Productivity in Kgs & 62.05 & 55.26 & 69.63 & 67.94 & 63.72 \\
\hline $\mathbf{0 9}$ & Fertilizer Productivity in Kgs & 09.94 & 08.69 & 10.98 & 10.40 & 10.00 \\
\hline
\end{tabular}

Farm Business income refers to profits and losses incurred through operation of the farm. A farm income statement is a summary of income and expenses that occurred during a specified accounting period or calculating period. The Farm Business Income was found to be higher in Nendran and Yelakki varieties which are respectively accounted for 4.22 lakhs and 3.54 lakhs. In respect of Farm Business Income also, the Poovan variety is capable of generating very low return.
Family Labour Income is the income to be generated from the farm because of their active involvement in crop production. Because of the family labour participation in the farm operations, the hired wage labour will equally be contributing to the productivity of the farm and hence the income in general could be enhanced. In this respect, the family labour income was assessed and the income is favorable in respect of Nendran variety and Yelakki variety of Banana. Both of the varieties are capable of contributing to 
the level of 3.53 lakhs and 2.86 lakhs respectively towards family labour income.

Return per Rupee of Investment is another appraising tool in which how much return a farmer could generate for a rupee of invested money in the crop production activities. Here, the Banana varieties are offering a different rate of return per rupee of investment. The return per rupee of investment is favorable with Nendran and Yelakki varieties of Banana which are capable of yielding 1.75 and 1.63 respectively. It implied that for one rupee of investment in Nendran variety of Banana, it is capable of generating 75 paise as net return to the farmer. In an overall perspective, anything more than a rupee is the profit. Efficient resource management and time bound application in split doses as per the recommended technology alone could enhance the return per rupee of investment. A study conducted by Ramakrishna etal. during 2017 indicated that the small farms are less productive in respect of Banana and the medium and large farms are able to generate higher return per rupee of investment. However, contribution to specific inputs like labour and fertilizer is also important and hence these details are analyzed and the results are presented in Table 8.

In respect of input productivity, two inputs were mainly considered as it contributes greatly to the output of Banana. In this respect, on examining the labour productivity, one unit of labour force effectively utilized in the production of Banana, it could be able to deliver around $64 \mathrm{kgs}$ of Banana on an average. But, the labour productivity was much higher in respect of Rasthali variety which stood at $68 \mathrm{kgsand}$ the same was found to be around $70 \mathrm{kgs}$ in Poovan and $62 \mathrm{Kgs}$ in respect of Yelakki varieties. But the labour productivity was found to be dismal in respect of Nendran variety of Banana. The reason might be due to the genetic potential of the variety and it consumes higher labor for different operations.

Another important input is the fertilizer. For every level of fertilizer application as recommended by the technocrats coupled with water management would definitely contribute to enhanced level of productivity. When comparing the actual productivity obtained for the fertilizer input across the varieties, the fertilizer productivity was found to be the highest in respect of Poovan variety followed by Rasthali and Yelakki which are respectively accounted for 10.98, 10.40 and $9.94 \mathrm{kgs}$ per ha. If the farm households apply one unit of fertilizer to the production of Banana, it would be able to deliver the output to the tune of $11 \mathrm{Kgs}, 10.40 \mathrm{Kgs}$ and $10 \mathrm{Kgs}$ respectively. From the input productivity, one could understand that the production of Banana is not scientifically practiced in the study environment and hence the poor yield in certain varieties could be seen and hence proper awareness on technology adoption either through workshops or training to the farm households are much important in this context.

In conclusions and policy options an economic appraisal of different varieties of Banana outlined that the Nendran and Yelakki varieties are capable of fetching highest return per ha. This is visible through costs and returns analysis and through the farm efficiency measures. Besides, the varieties like Rasthali and Poovan are able to generate less return. But the labor and fertilizer productivity outlined that the Poovan and Rasthali varieties have resource potentials. If resources are aptly used on time, they could generate higher return on par with the varieties like Nendran and Yelakki. In this context, it is reiterated that the resource use is found to be inappropriate and hence recommended technological practice and time bound input application would impart the 
genetic potential of different varieties of Banana and hence awareness creation exercise among the farm households about technology adoption need to be carried out by the Department of Horticulture and Plantation Crops. The NRCAB can also join with this venture to upscale the productivity of Banana by practicing appropriate schemes in the farm lands.

\section{References}

Agarwal, P.K., P. Yadav and S. Mandal (2018) "Economic Analysis of Cost and Return Structure of Paddy cultivation under Traditional and SRI Method: A
Comparative Study" International Journal of Agriculture Sciences, 10 (8): pp. 5890-5893.

Nandhini, U.S., T. Alagumani and S. Shibi, (2006), "Economic Analysis of Agriculture in Southern Parts of Coastal India”, Agricultura Tropicaet Subtropica, 39 (4): pp. 279-284.

Ramakrishna, M., K.N. Ravikumar and I. Bhavani Devi (2017) "A Micro Economic Analysis of Production of Banana in Kurnool District of Andhra Pradesh", International Journal of Current Microbiology and Applied Sciences, 6 (7): pp. 1152-1159

\section{How to cite this article:}

Karthikeyan, M., Zhou Deyi and Sekhar, C. 2021. An Investment Pattern in Banana Plantations of Tamil Nadu. Int.J.Curr.Microbiol.App.Sci. 10(02): 483-501.

doi: https://doi.org/10.20546/ijcmas.2021.1002.057 